\title{
Pre-Service English Teachers' Perception towards Online Assessment Method
}

\author{
Marisa Yoestara ${ }^{1}$, Zaiyana Putri ${ }^{2 *}$, Meta Keumala ${ }^{3}$, Zahratul Idami ${ }^{4}$ \\ ${ }^{1}$ Universitas Serambi Mekkah, Banda Aceh, Indonesia, marisayoestara@yahoo.com \\ ${ }^{2}$ Universitas Serambi Mekkah, Banda Aceh, Indonesia, zaiyana.putri@ serambimekkah.ac.id \\ ${ }^{3}$ Universitas Syiah Kuala, Banda Aceh, Indonesia, meta.keumala@gmail.com \\ ${ }^{4}$ IAIN Zawiyah Cot Kala, Langsa, Indonesia, zahratul21idami@gmail.com
}

Submitted: 22/04/2020 Revised: $12 / 05 / 2020 \quad$ Accepted: 19/05/2020

How to cite this article: Yoestara, M., Putri, Z., Keumala, M., \& Idami, Z. (2020). Pre-service English teacher's perception towards online assessment method. IJELR: International Journal of Education, Language, and Religion, 2(1), 1-10. https://doi.org/10.35308/ijelr.v2i1.1933

\begin{abstract}
This study aims to figure out pre-service English teachers' perception towards online testing system. In this study, the writers employed questionnaire to collect the data, and it was distributed to a total of 82 English Department students in Banda Aceh and Langsa City, Aceh. The questionnaire was developed based on a relevant previous study's questionnaire, and in this study, the questionnaire itself was conducted in Google form consisted of 13 questions that asked about the university students' perception about online test. Then all obtained data were analyzed by using percentage formula. The findings indicate that $63 \%$ or 55 respondents have positive perception toward online assessment. On the other hand, the negative perception goes to the other $37 \%$ or 27 respondents.
\end{abstract}

\section{Keywords}

Pre-service teachers; perception; online assessment; English language teaching; language assessment

\section{Introduction}

The rapid development of Information Communication and Technology (ICT) in the world today is undeniable. The ICT implementation itself also cannot be separated in educational world, since it can bring many benefits towards both educators and students (Suryani, 2010). It is also believed that, by implementing ICT in education, the goals of teaching and learning can be obtained more easily. Then other advantages are teachers can give online materials for students and assess the students' work through website or application. Due to the reasons, the lecturers are also urged to replace the old method of teaching with the modern one that is by implementing ICT in the teaching and learning process.

In order to know whether the goals of education are already achieved or not, the educators can evaluate their students through some assessments. Then assessment also seen as the measurement of students' knowledge, motivation, and diagnosing the learners' achievement in learning process (Jabbarifar, 2009; Newstead, 2004). Assessment itself can inform the educators about how to improve the teaching method 
that functionally used as the feedback. Therefore, assessment is important since it has a strong impact onlearning and it can be said as the core element of any formal education (Angus \& Watson, 2009).

There are many types of assessments that are usually used by educators in assessing their students. However, in this study the writers only focus on pre-service English teachers on online assessment models. Then Buchanan (2001) as cited in Cakiroglu, Erdogdu, Kokoc, and Atabay (2017) point out that students' academic achievement can also be effectively evaluated by online assessment method, although the percentage of class attending are rarely done.

In line with the previous statement, online assessment can be said as the alternative in assessing the students. Online assessment can be said as the process of assessing students by using website or application. The main advantages of online assessment are the flexibility of time and place of the test (Baleni, 2015). Moreover, online assessment also gives educators other advantages, such as auto correcting, quality feedback, valid and reliable, economic and ecological, practical and fun discussion (Khairil \& Mokshein, 2018; Peat \& Franklin, 2002).

Some studies have been done related to this matter. The first study by Cirit (2015) entitle Assessing ELT Pre-Service Teachers via Web 2.0 Tools: Perceptions toward Traditional, Online and Alternative Assessment. It is found that the participants' perception toward the alternative assessment via web 2.0 tools were positive. Then Khan and Khan (2019) revealed that most of their participants agree that they felt comfortable with online assessment. Then Alruwais (2018) also found that there are some benefits of using E-assessment, and they can be mentioned as follows: students can get direct and immediate feedback.

Secondly, it can improve student performance. Then it can minimize teachers' time and effort. After that, it also saves the institution budget. Lastly, e-assessment also can increase students higher-order thinking skill. Furthermore, a study by Alsodoon (2017) claimed that Saudi students have positive perception towards online assessment and they even were satisfied as online assessment has features of immediate feedback and effective grading method. Finally, a study by Amalia (2018) entitle Students' Perception of Online Assessment use in Schoology in EFL Classrooms. She surveyed 120 English Teacher Education Department students by employing a set of questionnaires. The findings showed that the students have positive perceptions toward the use of online assessment. To wrap up, based on the above explanation, online assessment gives many benefits towards education, especially in teaching and learning process.

Even though there are some similar studies, but the study that focusing on university students is still limited to be found. In order to achieve the effectiveness and improve the students' academic achievement, educators is required to looking for students' preferences regarding to the assessment that will be conducted, if they are ready for the transition from traditional to online assessment (Khan \& Khan, 2019). Thus, empirical studies are still needed to explore the benefits of the online assessment methods. The fact that some lecturers also use ICT in teaching and learning process at English Department in some universities in Aceh, Indonesia encourage the pre-service English teachers to do so, particularly when they tech in the schools/universities. Mostly, they implement ICT in delivering subject matter and assessing students' assignment which is submitted online. Therefore, this study is aimed to figure out Pre-Service English Teachers' perspective towards online assessment.

\section{Method}

This study is a descriptive study which mainly aims to describe a social phenomenon or a particular issue (Creswell, 2014). In this study, the researchers intended to find out the pre-service English teachers' perception toward online assessment or online test. 
The sample in this study consisted of 82 pre-service English teachers in the $4^{\text {th }}, 6^{\text {th }}$, and $8^{\text {th }}$ semester who already experienced doing the online test. There are 12 males and 70 females from English Department in two universities, namely Serambi Mekkah University and IAIN Zawiyah Cot Kala Langsa, Aceh.

To collect the data, the researchers adapted the questionnaire to find out the pre- service English teachers' perception from the previous study by Alsadoon (2017), entitled Students' Perceptions of EAssessment at Saudi Electronic University. The Cronbach alpha of the questionnaire was found to be = .91 which is considered a high value and means that this questionnaire was reliable enough to use. However, the adaptation process is done. For example, in this study the researchers added the Bahasa translation to ease the participant to answer the questionnaire. Additionally, the items in the previous questionnaire were adjusted to fit in the context and irrelevant items were deleted or substituted. The final questionnaire consisted of 13 items and was then distributed to all of the targeted samples through google form.

The collected data were analyzed by finding out the perception of each item asked in the questionnaire to find out the pre-service English teachers' perception towards online assessment. The findings are then elaborated in detail.

\section{Results \& Discussion}

To begin with, the first statement in the questionnaire asked respondents' perception whether online test is more interesting than traditional test. The chart shows that $60,5 \%$ or 50 teachers agree with the statement. The second highest score is $25,9 \%$ or 24 of them disagree with it. And the rest, some of them strongly agree and strongly disagree with the statement. It is clear that the test done through online is attractive. It is clear from these results that online tests attract more examinees.

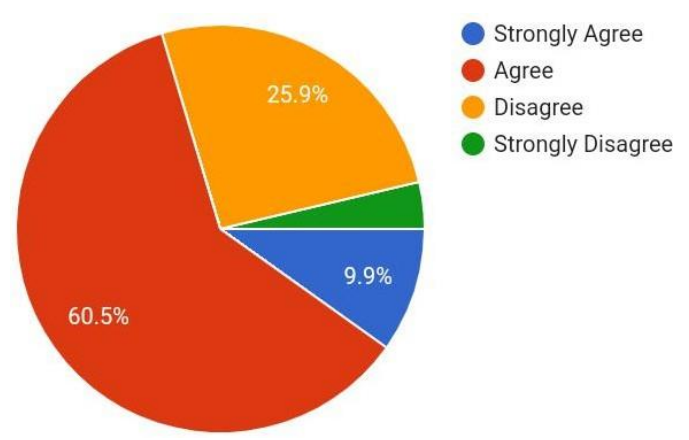

\section{Picture 1. Online Test is More Interesting than Traditional Test}

The second statement states that online test could ease the assessment process. The highest result has the same value with the previous statement. There are $60,5 \%$ or 50 teachers agree while $22,2 \%$ or 18 disagree with it. However, there are also $14,8 \%$ or 12 people strongly agree with it. The rest $2,5 \%$ or 2 people strongly disagree. The data shows that online tests can simplify the assessment process so that it takes place more easily. 


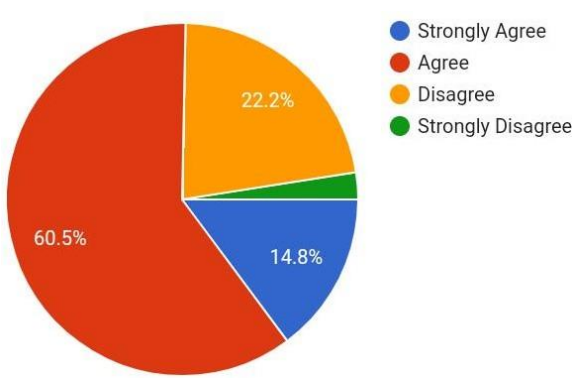

\section{Picture 2. Online Test Could Ease the Assessment Process}

Third, Picture 3 shows the same portion for agree and disagree which is $42 \%$ or 34 people say that online test is a good tool to evaluate students, but some do not recommend it. The rest shares almost the same percentage that they strongly agree and strongly disagree with the statement which is $8,6 \%$ or 7 people. More than half of respondents agree that online tests can be a good way to assess students.

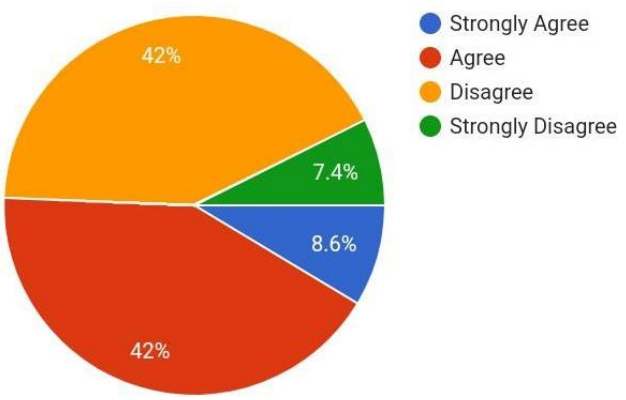

\section{Picture 3. Online Test is a Good Tool to Evaluate Students}

Fourth, $60,5 \%$ or 50 respondents agree with the statement that online test is easy to design, even $16 \%$ or 5 people strongly agree with it. Meanwhile according to $22,2 \%$ or 19 people online test is not easy to design, even $1,7 \%$ of them strongly disagree with the issue. In this section, it is obvious that more respondents agree that online tests are easier to plan, design and create.

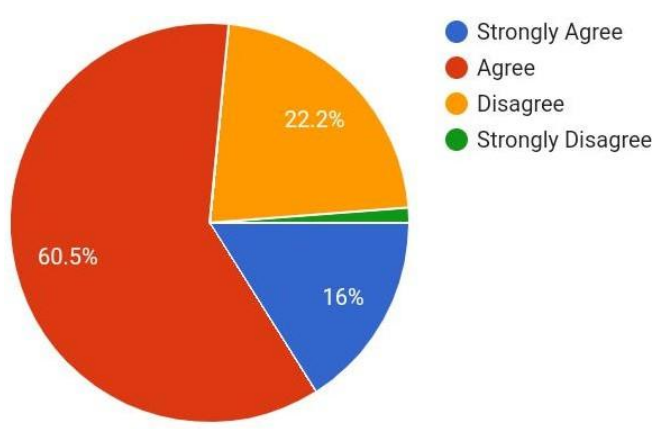

\section{Picture 4. Online Test is Easy to Design}

Fifth, $54,3 \%$ of the teachers agree that online test is easy to implement while the rest shows that $27,2 \%$ disagree and 18,5 strongly disagree with the statement. This means that the use of online tests is considered easier to be used by pre-service English teachers. 


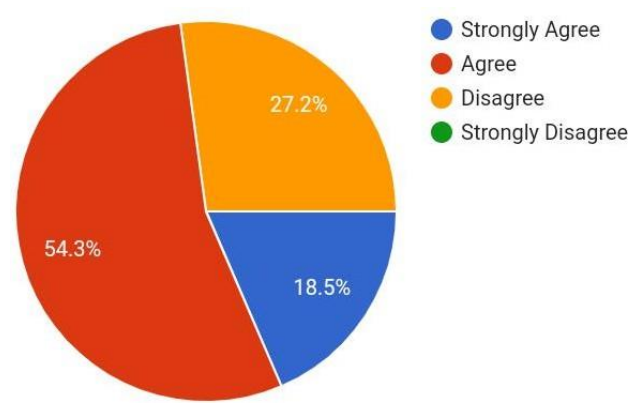

\section{Picture 5. Online Test is Easy to Implement}

Sixth, for $60,5 \%$ or 50 respondents, online assessment could save money. Even $29,6 \%$ strongly agree with it. However, there are $9,9 \%$ or 8 of them disagree with the statement. Therefore this online test is also considered to be more financially efficient.

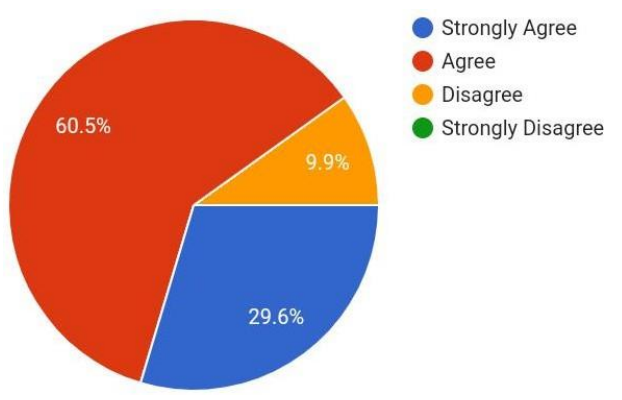

\section{Picture 6. Online Assessment Could Save Money}

The seventh variable is asking for agreement toward the statement that online assessment could save time. According to $42 \%$ of the respondents or 35 people agree while on the other hand, 30,9\% or 25 of them thought that online assessment could not save money. The rest, $21 \%$ or 17 respondents and $6,2 \%$ or 5 of them strongly agree and strongly disagree about this idea. Besides being able to save money, online test is also considered by almost some respondents, it can save time.

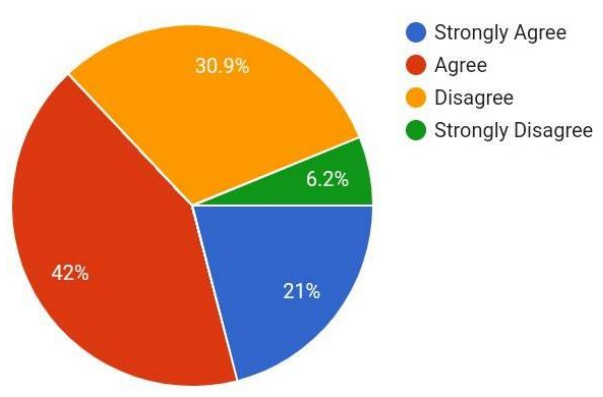

\section{Picture 7. Online Assessment Could Save Time}

Furthermore, the eighth picture shows that more than $90 \%$ of the sample agree and even strongly agree that online assessment saves paper. Meanwhile there are only $5 \%$ or 4 people who said that online assessment did not save paper. It meant there were 78 respondents on the former. This displays that the 
paper used during a manual test can be reduced completely by not using it at all when conducting an online test.

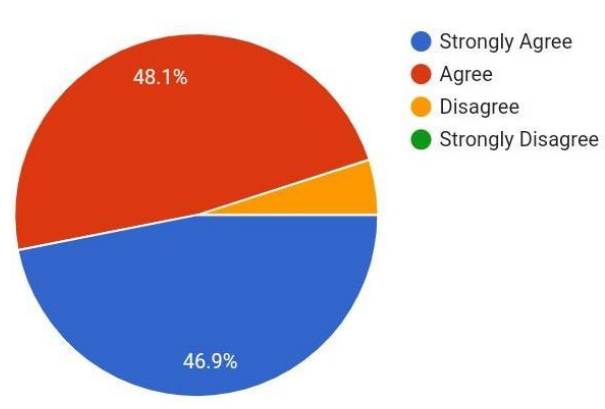

\section{Picture 8. Online Assessment Saves Paper}

Moreover, the next variable asking respondents' perception towards the statement whether online assessment is easy to mark. There are $48,1 \%$ or 40 people thought the same way but 33,3\% or 27 people had the different perception. Besides, $14,8 \%$ or 12 respondents strongly agree and support the idea, and the rest $3,8 \%$ or 3 respondents strongly disagree. For almost all of the respondents, online assessment is easy to be marked in the assessment effort.

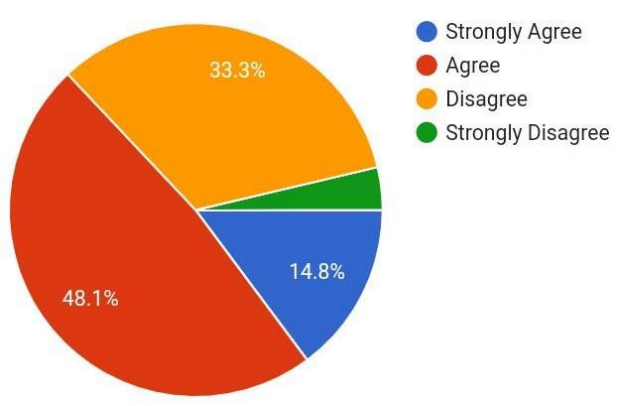

Picture 9. Online Assessment is Easy to Mark.

The tenth statement states that online assessment is appropriate for all skills in English lesson. There are $45,7 \%$ or 38 people disagree with the statement while $32,1 \%$ or 26 people agree with it. The rest, $13,6 \%$ or 11 respondents strongly disagree but there were $8,6 \%$ or 7 people strongly agree with the issue. In this variable it is clear that the respondent did not approve the statement. Respondents assume that online assessment cannot be maximally used for all skills in English lessons.

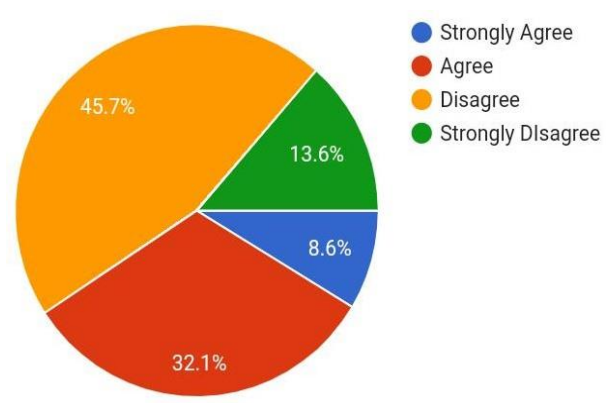

Picture 10. Online Assessment is Appropriate for all Skills in English Lesson This article is licensed under CC BY-SA 4.0 License 
Moreover, 55,6\% or 46 respondents disagree with the statement that online assessment is appropriate for all students. However, $25,9 \%$ or 22 students agree. While 14,8\% strongly disagree, the other 3,7\% or 4 people responded that online assessment really appropriate for all students. For pre-service English teachers online assessment is considered suitable for all students with different abilities.

Online assessment is an important step inside the e-learning process because gives convenient feedback to all participants in the process, helping to improve the learning and teaching experience. Online assessment is an important step inside the e-learning process because gives convenient feedback to all participants in the process, helping to improve the learning and teaching experience. Online assessment is an important step inside the e-learning process because gives convenient feedback to all participants in the process, helping to improve the learning and teaching experience.

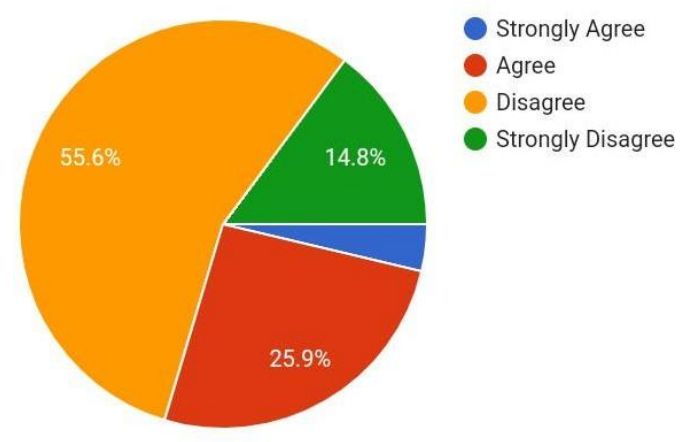

\section{Picture 11. Online Assessment is Appropriate for all Students}

In addition, there was also a statement stated that online assessment does not facilitate cheating. The responses are varied but almost half of the repondents agree with it, that was 40, 7\% or 33 people, the other $35,8 \%$ or 30 respondents disagree, $11,1 \%$ or 9 of them strongly disagree and the rest $12,3 \%$ or 10 of the respondents strongly agree. In conclusion, online tests cannot make students cheat with friends during the exam process.

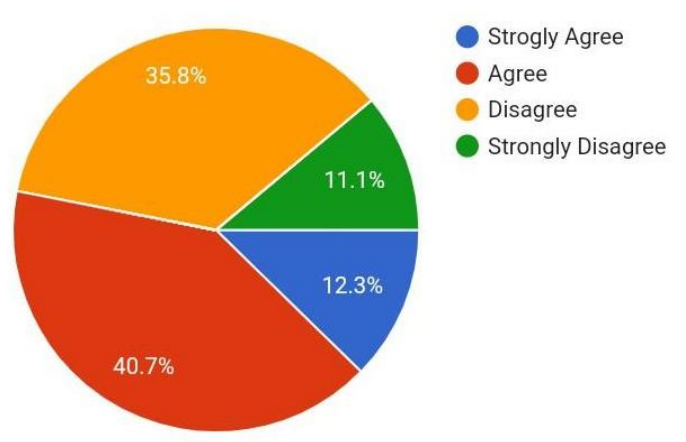

\section{Picture 12. Online Assessment does not Facilitate Cheating}

Last, the statement "online assessment reduces exam stress" are agreed by $49,4 \%$ or 41 respondents, on the other hand there were also $28,4 \%$ or 23 people disagree and the rest, $12,3 \%$ or 10 of them strongly disagree, and $9,9 \%$ or 8 people strongly agree. In this case, online assessment is able to make students more relaxed in completing exam questions. 


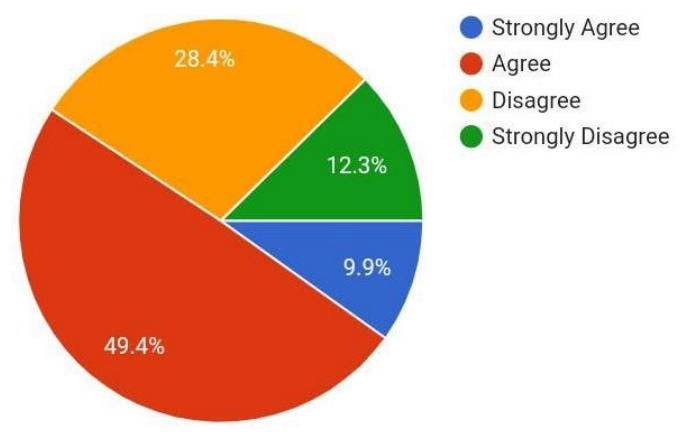

Picture 13. Online Assessment Reduces Exam Stress

All of the thirteen items above is related to the situation of online assessment and the perceptions of preservice English teachers have toward the issue. As it has mentioned above, online assessment offers one way to assistant the teachers in order to assess their students. According to what the researchers analyzed the respondents' answers, all thirteen items shows that more than half of the samples agree and satisfy with online assessment. Some items, such as the first items even describes that only 8 respondents out of 82 disagree with the idea stated that online assessment is more interesting than traditional one. Moreover, there was only $5 \%$ or 4 people who think that online assessment could not save paper, but the rest 78 people agree and strongly agree with the idea. This too is in line with the items number 6 and 7 which say that online assessment could save money and time. More than half of the samples respond positively. These results then support the previous statement by Baleni (2015) as explained in the previous chapter.

Furthermore, this article also finds that the more than half of 82 pre-service English teachers get the same idea with the items say that online assessment could ease teachers in the process of assessment, in designing the test, in implementing the assessment, and in marking the students' work. The result shows that the percentages of positive perception are bigger in every single item of the statements.

In addition, the other items which mention that online assessment is a good tool to evaluate, does not facilitate cheating, appropriate for all skills in English lesson and for all students, and it could reduce stress were also supported by more than half of the respondent. Then the results of the data show that $63 \%$ or 55 pre-service English teachers support the online assessment method to be implemented, meanwhile the other $37 \%$ or 27 respondents feel dissatisfied with this method to be used in the lesson.

Henceforth, according to the results, it is showed that this research supports the previous studies related to the topic of online assessment. As the research from Cirit (2015) entitled sssessing ELT pre-service teachers via web 2.0 tools: Perception toward traditional, online and alternative assessment which concluded that most of the participants had positive perception toward online assessment, so as the result of this research. Moreover, this article also in line with the result of others previous ones, for instance the articles from Khan and Khan (2019), Alruwais (2018), and Alsodoon (2017). Then the result of this research also supports the research conducted by Amalia (2018) entitle Students' Perception of Assessment Use in Schoology in EFL Classroom which found that the students owned positive perception toward the use of online assessment.

\section{Conclusion}

The data analysis above lead to a conclusion that most of pre-service English teachers which are participated as the sample of this article has positive perception toward online assessment method. More than half of the numbers of respondents claim that they agree and even strongly agree to the method of 
assessment. Based on the results, the respondents whose perceptions are positive agree to the items which state that online assessment is more interesting than traditional one and it is a good tool to evaluate students. The positive perceptions also support that online assessment could ease the assessment process, does not facilitate cheating, and appropriate for all English skills and for all students. Besides, it is found that most of the respondents have the same direction that online assessment is easy to design and easy to implement. It also can save money, time, and paper. In brief, this research showed that $63 \%$ or 55 respondents have positive perception, agree and strongly agree, toward online assessment. On the other hand, the negative perception goes to the rest $37 \%$ or 27 respondents who disagree and strongly disagree toward the method.

\section{Acknowledgement}

We would like to thank the dean and head of English Education Department in University of Serambi Mekkah and in IAIN Zawiyah Cot Kala for facilitating this study, by allowing the students to participate in this study. Furthermore, the hard work of each writer in this study is truly appreciated to complete this study.

\section{Author Contribution and Competing Interest}

In this paper, each author has the same contribution. The first author (Marisa Yoestara) is responsible in creating the instruments and writing the research methodology. Then the second author (Zaiyana Putri) is responsible to write the introduction. Meanwhile, the third author (Meta Keumala) is analyzing the findings and results of the study. Furthermore, the last author (Zahratul Idami) is dealing with discussion of the result of the study. All authors are responsible in distributing the instrument of the study, and contributed to the final manuscript.

\section{References}

Alruwais, N., Wills, G., \& Wald, M. (2018). Advantages and challenges of using eassessment. International Journal of Information and Education Technology, 8(1), 34-37.

Alsadoon, H. (2017). Students' perceptions of E-assessment at Saudi Electronic University.TOJET: The Turkish Online Journal of Educational Technology,16(1), 147-153

Amalia, R. (2018). Students' perception of Online Assessment use in Schoology in EFL Classrooms (Doctoral dissertation, UIN Sunan Ampel Surabaya).

Angus, S. D., \& Watson, J. (2009). Does regular online testing enhance student learning in the numerical sciences? Robust evidence from a large data set. British Journal of Educational Technology, 40(2): 255-272.

Baleni, Z. G. (2015). Online formative assessment in higher education: Its pros and cons. Electronic Journal of e-Learning, 13(4), 228-236.

Cakiroglu, U., Erdogdu, F., Kokoc, M., \& Atabay, M. (2017). Students' preferences in online assessment process: Influences on academic performances. Turkish Online Journal of Distance Education, 18(1), 132-142.

Cirit, N. C. (2015). Assessing ELT Pre-Service Teachers via Web 2.0 Tools: Perceptions toward Traditional, Online and Alternative Assessment. Turkish Online Journal of Educational Technology-TOJET, 14(3), 9-19.

Creswell, J. W. (2014). Educational research: Planning, conducting, and evaluatingquantitative and qualitative research (4th ed.). Boston: Pearson.

Jabbarifar, T. (2009). The importance of classroom assessment and evaluation in educational system. In Proceedings of the 2nd International Conference of Teaching and Learning (pp. 1-9).

Khairil, L. F., \& Mokshein, S. E. (2018). 21st century assessment: online assessment. International Journal of Academic Research in Business and Social Sciences, 8(1), 659-672. 
Khan, S., \& Khan, R. A. (2019). Online assessments: Exploring perspectives of university students. Education and Information Technologies, 24(1), 661-677.

Newstead, S. (2004). The purposes of assessment. Psychology Learning \& Teaching, 3(2), 97-101.

Peat, M., \& Franklin, S. (2002). Use of online and offline formative and summative assessment opportunities: have they had any impact on student learning?. In ASCILITE (pp. 505-513).

Suryani, A. (2010). ICT in education: Its benefits, difficulties, and organizational development issues. Jurnal Sosial Humaniora, 3(1), 13-33. 